\title{
HUBUNGAN ANTARA DERAJAT PENYAKIT GINJAL KRONIK DENGAN NILAI AGREGASI TROMBOSIT DI RSUP PROF. DR. R. D. KANDOU MANADO
}

\author{
${ }^{1}$ Melti Tandi \\ ${ }^{2}$ Arthur Mongan \\ ${ }^{2}$ Firginia Manoppo
}

\author{
${ }^{1}$ Kandidat Skripsi Fakultas Kedokteran Universitas Sam Ratulangi Manado \\ ${ }^{2}$ Bagian Patologi Klinik Fakultas Kedokteran Univrsitas Sam Ratulangi Manado \\ Email: meltitandi@gmail.com
}

\begin{abstract}
Chronic kidney disease has got a lot of attention and more widely studied despite reached end stage renal failure, patients still live a long life witha fairly good quality of life although the prevalence is increases throughout the year. one of the circumstances in chronic kidney disease is uremia which is a clinical and laboratory syndrome that occurs inorgans. In uremia interference with platelet function, the production ofprostacyclinin blood vesselswould increase, and excessurea levels in blood would be a potential vasodilator and platelet aggregation antagonist. Methods: An analytic observational cross-sectional study. Samples were patients that diagnosed with chronic kidney disease at the Hospital Clinic of Nephrology-Hypertension Prof. Dr.R. D.Kandou Manado in December toFebruary 2014. Criteria included were patients $<80$ years old and has been diagnosed with chronic kidney disease in this case had done a physical examination and investigations by doctors, using medical record of urea-creatinine and also a complete blood countand platelet aggregation in Prokita Laboratory Manado. Forstatistical analysis used Shapiro-Wilk test also Pearson Correlations test. Result: There were 20 patients with chronic kidney disease sampled in this study. It was found that there is a relationship between of urea-creatinine and aggregation results in trace $\mathrm{ADP} 5(\mathrm{P}=0.004)$ while the value ADP10 no significant correlation( $\mathrm{P}=0.399)$. Conclusion: In chronic kidney disease patients, urea-creatininewiththe value of platelet aggregation intrace ADP5had a relation ship while intrace ADP10 had not a relationship.
\end{abstract}

Keywords: Chronic kidney disease, platelet aggregation.

Penyakit ginjal kronis semakin banyak menarik perhatian dan makin banyak dipelajari karena walaupun sudah mencapai gagal ginjal tahap akhir akan tetapi penderita masih dapat hidup panjang dengan kualitas hidup yang cukup baik di samping prevalensinya yang terus meningkat sepanjang tahun. ${ }^{1}$

Menurut United State Renal Data System di Amerika Serikat prevalensi penyakit ginjal kronis meningkat 20-25\% setiap tahun. ${ }^{2}$ WHO memperkirakan di Indonesia akan terjadi peningkatan penderita gagal ginjal pada tahun 1995-2025 sebesar 41,4\% dan menurut data dari Persatuan Nefrologi Indonesia (PERNEFRI) diperkirakan terdapat 70.000 penderita gagal ginjal di Indonesia, angka ini akan terus meningkat sekita $10 \%$ setiap tahunnya. $^{3}$ Di Sulawesi Utara sendiri penyakit ginjal kronis masuk dalam salah satu penyakit beresiko, menurut data RSUP Prof. DR. R. D. Kandou Manado Penderita penyakit ginjal kronik yang menjalani terapi hemodialisis 130 pasien dalam periode waktu 1 bulan, dimana setiap pasien memiliki jadwal pemeriksaan yang telah di tentukan untuk terapi.

Penyakit ginjal kronik adalah suatu proses patofisiologis dengan etiologi beragam, mengakibatkan penurunan fungsi ginjal yang progresif, dan pada umumnya 
berakhir dengan gagal ginjal. Selanjutnya gagal ginjal adalah suatu keadaan klinis yang ditandai dengan penurunan fungsi ginjal yang bersifat ireversibel, pada suatu derajat yang memerlukan terapi ginjal yang tetap, berupa dialisis atau transplantasi ginjal. Uremia adalah suatu sindrom klinik dan laboratorik yang terjadi pada semua organ, akibat penurunan fungsi ginjal pada penyakit ginjal kronik. ${ }^{4}$

Pada stadium paling dini penyakit ginjal kronik, terjadi kehilangan daya cadang ginjal (renal reserve), pada keadaan LFG (laju filtrasi glomerulus) masih normal atau meningkat. Kemudian secara perlahan akan terjadi penurunan fungsi nefron yang progresif, yang ditandai dengan peningkatan kadar urea dan kreatinin serum. Pada LFG sebesar 60\%, pasien masih belum merasakan keluhan tapi sudah terjadi peningkatan kadar urea dan kreatinin serum. Pada LFG 30\%, mulai terjadi keluhan seperti nokturia, badan lemah, mual, nafsu makan kurang, dan penurunan berat badan. Pada LFG $<30 \%$ pasien memperlihatkan gejala dan tanda uremia yang nyata, seperti anemia, pening-katan tekanan darah, mual dan sebagainya. Sedangkan pada LFG 15\% akan terjadi gejala dan komplikasi yang lebih serius antara lain dialisis atau transplantasi ginjal. ${ }^{5}$

Agregasi trombosit dapat meningkat pada keadaan uremia. Pada uremia dilaporkan terjadi gangguan pada fungsi trombosit. Produksi prostasiklin dalam pembuluh darah akan meningkat, dan kadar ureum berlebih dalam darah akan menjadi vasodilator potensial dan antagonis agregasi trombosit. ${ }^{6,7}$

\section{METODE PENELITIAN}

Penelitian ini bersifat analitik observasional dengan menggunakan desain potong lintang (cross sectional) dan dilaksanakan di Poliklinik NefrologiHipertensi bagian Ilmu Penyakit Dalam RSUP Prof. Dr. R. D. Kandou Manado. Pemeriksaan agregasi trombosit menggunakan 1 set agregometer ChronoLog model 490, Chrono-Log recorder model 707, Computer Windows based PC. Penelitian ini dilakukan sejak Desember 2013 sampai Februari 2014. Sampel penelitian yaitu 20 penyandang CKD non hemodialisa yang termasuk kriteria inklusi. Data dianalisis dengan uji Saphire Wilk dan uji Pearson Product Moment.

\section{HASIL PENELITIAN}

Tabel 1. Distribusi penderita penyakit ginjal kronik berdasarkan usia

\begin{tabular}{|c|c|c|}
\hline $\begin{array}{l}\text { Usia Sampel } \\
\text { Persen (\%) }\end{array}$ & f (orang) & $\%$ \\
\hline Kelompok usia <55thn & 3 & 15 \\
\hline Kelompok usia 55-70thn & 13 & 65 \\
\hline $\begin{array}{l}\text { Kelompok usia >70thn } \\
20\end{array}$ & 4 & \\
\hline $\begin{array}{l}\text { Total } \\
100\end{array}$ & 20 & \\
\hline
\end{tabular}

Tabel 2. Distribusi penderita penyakit ginjal kronik berdasarkan jenis kelamin

\begin{tabular}{lcc}
\hline Jenis Kelamin & $\begin{array}{c}\text { Frekuensi } \\
\text { (orang) }\end{array}$ & $\begin{array}{c}\text { Persen } \\
(\mathbf{\%})\end{array}$ \\
\hline Laki-laki & 6 & 30 \\
Perempuan & 14 & 70 \\
\hline Total & $\mathbf{2 0}$ & $\mathbf{1 0 0}$ \\
\hline
\end{tabular}

Subjek penelitian ini berjumlah 20 orang penyandang CKD non hemodialisa.

Usia yang termasuk kriteria inklusi ialah 40-80 tahun. Pada penelitian ini ditemukan lebih banyak subjek yang berusia $\geq 55$ tahun (85\%) dibandingkan usia $<55$ tahun (15\%) (Tabel 1). Sedangkan untuk jenis kelamin ditemukan lebih banyak subjek wanita (70\%) dan pria (30\%) (Tabel 2).

\section{Data nilai agregasi trombosit pada penyandang CKD non hemodialisa}

Data nilai agregasi trombosit pada CKD non hemodialisa dapat dilihat pada Tabel 3. Nilai agregasi trombosit dengan menggunakan ADP $5 \mu \mathrm{m}$ terendah yaitu 23\% dan tertinggi yaitu 92\%, sehingga diperoleh nilai rata-rata sebesar 41,60\% (dibulatkan 42\%) dengan simpang baku $16,30 \%$. Pada nilai agregasi trombosit dengan menggunakan 
ADP $10 \mu \mathrm{m}$ terendah yaitu $28 \%$ dan tertinggi $72 \%$, sehingga diperoleh nilai ratarata sebesar 47,10\% (dibulatkan dengan 47\%) dengan simpang baku 11,54\%.

Tabel 3. Nilai agregasi trombosit

\begin{tabular}{|c|c|c|c|c|c|c|c|}
\hline \multicolumn{2}{|c|}{$\begin{array}{l}\text { Agregasi } \\
\text { Trombosit }\end{array}$} & \multicolumn{2}{|c|}{ Frekuensi } & $\begin{array}{l}\text { Rata- } \\
\text { rata }\end{array}$ & $\begin{array}{l}\text { Nilai } \\
\text { terendah }\end{array}$ & $\begin{array}{l}\text { Nilai } \\
\text { tertinggi }\end{array}$ & $\mid \begin{array}{l}\text { Simpanga } \\
\text { baku! }\end{array}$ \\
\hline & & $\mathrm{N}$ & $\%$ & \multirow{4}{*}{41.60} & \multirow{4}{*}{23} & \multirow{4}{*}{92} & \multirow{4}{*}{16.304} \\
\hline \multirow{4}{*}{ ADP 5} & hipo & l & 5 & & & & \\
\hline & normo & 18 & 90 & & & & \\
\hline & hiper & l & 5 & & & & \\
\hline & hiper & 0 & 0 & 47.10 & 28 & 72 & 11.548 \\
\hline \multirow[b]{2}{*}{ ADP 10} & hipo & 13 & 65 & & & & \\
\hline & normo & 7 & 35 & & & & \\
\hline
\end{tabular}

\section{Korelasi jumlah kreatinin dengan agregasi trombosit}

Pertama-tama dilakukan uji normalitas data untuk melihat apakah distribusi data normal atau tidak. Hasil uji normalitas data menggunakan uji saphire wilk dan didapatkan nilai $p$ pada kreatinin dan ADP 5 sebesar 1.000 berarti $p$ value $>0.05$ sedangkan nilai p pada kreatinin dan ADP 10 sebesar 0.637 berarti $p$ value $>0,05$. Hal ini berarti distribusi dari data normal. Dengan demikian, disimpulkan bahwa data ini menggunakan Uji Pearson product moment.

Hasil uji Pearson product moment terhadap korelasi nilai Kreatinin dan Agregasi Trombosit menunjukkan nilai ADP5 $p=0.004$ yang berarti $p$ value 0,05 nilai alpha terdapat hubungan antara kadar kreatinin dengan nilai agregasi trombosit sedangkan ADP10 $\mathrm{p}=0$,399 yang berarti bahwa p value $\geq 0,05$ nilai alpha yang dapat disimpulkan bahwa, tidak terdapat hubungan yang signifikan antara nilai kreatinin pasien dengan agregasi trombosit.

\section{BAHASAN}

Pada penelitian ini jumlah subjek penelitian yang memenuhi kriteria inklusi ialah 20 orang di Poliklinik NefrologiHipertensi bagian Ilmu Penyakit Dalam RSUP. Prof. Dr. R. D. Kandou Manado lalu diambil sampel darahnya dan diperiksa nilai agregasi trombositnya di laboratorium Prokita Manado.

Menurut United State Renal Data System di Amerika Serikat prevalensi penyakit ginjal kronis meningkat 20-25\% setiap tahun. ${ }^{2}$ WHO memperkirakan di Indonesia akan terjadi peningkatan penderita gagal ginjal pada tahun 1995-2025 sebesar 41,4\% dan menurut data dari Persatuan Nefrologi Indonesia (PERNEFRI) diperkirakan terdapat 70.000 penderita gagal ginjal di Indonesia, angka ini akan terus meningkat sekitar $10 \%$ setiap tahunnya dan menunjukkan bahwa pertambahan usia merupakan salah satu faktor resiko terjadinya penyakit CKD. Hasil penelitian ini menunjukkan jumlah usia tuæ 55( tahun) lebih banyak dibandingkan usia dewasa ( $<55$ tahun). Pada penelitian ini jenis kelamin wanita dan pria memiliki jumlah yang berbeda.

Interpretasi nilai normal yang digunakan oleh peneliti menggunakan standar nilai normal laboratorium Prokita Manado yaitu: nilai ADP $5 \mu \mathrm{m}$ 25-68\% dan nilai ADP $10 \mu \mathrm{m}$ 49-84\%. Pada penelitian ini, interpretasi nilai agregasi trombosit untuk penyandang CKD non hemodialisa dengan ADP 5 menunjukkan nilai normal (normoagregasi) sedangkan pada ADP 10 menunjukkan nilai hipoagregasi.

Menurut peneliti hal ini disebabkan oleh berbagai macam faktor yang mempengaruhi baik kreatinin maupun agregasi trombosit itu sendiri. ${ }^{5}$

Pada stadium paling dini penyakit ginjal kronik, terjadi kehilangan daya cadang ginjal (renal reserve), pada keadaan LFG (laju filtrasi glomerulus) masih normal atau meningkat. Kemudian secara perlahan akan terjadi penurunan fungsi nefron yang progresif, yang ditandai dengan peningkatan kadar urea dan kreatinin serum. Pada LFG sebesar 60\%, pasien masih belum 
merasakan keluhan tapi sudah terjadi peningkatan kadar urea dan kreatinin serum. Pada LFG 30\%, mulai terjadi keluhan seperti nokturia, badan lemah, mual, nafsu makan kurang, dan penurunan berat badan. Pada LFG <30\% pasien memperlihatkan gejala dan tanda uremia yang nyata, seperti anemia, peningkatan tekanan darah, mual dan sebagainya. Sedangkan pada LFG 15\% akan terjadi gejala dan komplikasi yang lebih serius antara lain dialisis atau transplantasi ginjal. ${ }^{5}$

Agregasi trombosit dapat meningkat pada keadaan uremia. Pada uremia dilaporkan terjadi gangguan pada fungsi trombosit. Produksi prostasiklin dalam pembuluh darah akan meningkat, dan kadar ureum berlebih dalam darah akan menjadi vasodilator potensial dan antagonis agregasi trombosit.,

Hasil penelitian melalui uji Pearson product moment mendapatkan bahwa tidak terdapat hubungan signifikan antara nilai kreatinin dan agregasi trombosit pada penderita penyakit ginjal kronik di RSUP Prof.Dr.R.D.Kandou Manado. Hasil tersebut ditemukan karena $\mathrm{p}$ value lebih besar daripada nilai alpha $(0,05)$.

Keterbatasan penelitian ini ialah terbatasnya jumlah sampel, kadar agonis ADP $5 \mu \mathrm{m}$ dan $10 \mu \mathrm{m}$, dan waktu penelitian yang singkat untuk pengumpulan dan pengolahan sampel.

\section{SIMPULAN}

Berdasarkan hasil penelitian ini maka dapat disimpulkan bahwa usia beresiko untuk penyakit CKD adalah usia tuax 55 tahun) mayoritas berjenis kelamin wanita dan tidak terdapat hubungan yang signifikan antara penyandang CKD non hemodialisa dengan nilai agregasi trombosit.

\section{SARAN}

Untuk penelitian lanjutan, jumlah sampel penelitian perlu ditingkatkan untuk menghindari terjadinya bias dalam penelitian. Dapat juga digunakan berbagai kadar agonis ADP (1, 2, 5 dan $10 \mu \mathrm{m})$ agar ketelitian interpretasi nilai agregasi trombosit lebih efektif. Penelitian ini dapat juga dilakukan pada penyakit-penyakit kardiovaskular, penyakit endokrinmetabolik dan pengguna obat-obatan sejenis aspirin, kortikosteroid dan antidiabetik.

\section{DAFTAR PUSTAKA}

1. Lubis AJ, 2006. Dukungan soal pada pasien gagal ginjal terminal yang melakukan terapi hemodialisis. Fakultas Psikologi USU. Available from: http://www.library.usu.ac.id/download/fk/06 010311.pdf [accesed 3 jan 2014]

2. The united states renal data system.2013. Incidence, prevalence, patient characteristics and treatment modality. available from: http//www.usrds.org/

3. Yeger MC.Overview of stem cell biology.in : Hoffman R, Jr EJB, Shattil SJ et al. Hematology Basic Principles and Practice ${ }^{\text {5th }}$ ed.2008

4. Suwitra K. Penyakit ginjal kronik. Dalam sudoyo aru w, setiyohadi bambang, Alwi idrus. Editors: Buku Ajar Ilmu Penyakit Dalam. Jilid II, Edisi V. Jakarta. Interna publishing;2009.h.1035

5. Suwitra K. Penyakit ginjal kronik. Dalam sudoyo aru w, setiyohadi bambang, Alwi idrus. Editors: Buku Ajar Ilmu Penyakit Dalam. Jilid II, Edisi V. Jakarta. Interna publishing;2009.h.1036

6. Sengupta A, Ghosh M.Modulation of platelet aggregation, haematological and histological parameters by structured lipids on hypercholesterolaemicrats. AOCS : 2010

7. Haszon I, Papp F, Kovacs $\mathbf{J}$ et al.platelet aggregation, blood viscosity and serum lipids in hypertensive and obese children. Eur J Pediatr.2003;162:385-390

8. Harrison P. Platelet Function Analysis. Elsevier.2005; 19: 111-23

9. Sirotkina OV, Zabotina AM, Taraskina AE et al.Participation of IIb-IIIa glycoprotein in spontaneous platelet aggregation.Translated from Byulleten' Eksperimental'noi Biologii i Meditsiny, Vol. 143, No. 4. 2007:398-401

10. Hayward CPM, Moffat K, Raby A et al. Development of north American consensus guidelines for medical laboratories that perform and interpret platelet function testing using light transmission aggregometry. Am J Clin Pathol. 2010;134:955-963 
11. Wirawan R. Nilai Rujukan Pemeriksaan Agregasi Trombosit dengan Adenosis Difosfat Pada Orang Indonesia Dewasa Normal di Jakarta. Majalah Kedokteran Indonesia.2007; 57:215

12. Kelton JG, Powers $P$, Julian $P$ et al.Sex related differences in platelet aggregation: influence of the hematocritin bloodjournal.hematologylibrary/org. Vol. 56,No. 1.1980

13. Jackson SP. The growing complexity of platelet aggregation.2007; 109:5087-95. Available from: http://bloodjurnal.hematologylibrary.org/co ntent/109/1205087.full

14. Perry S, Ortel TL. Nephrology. In Key N , Mikhel M, O;shaugnessy $D$ et al. Editors: Practical hemostasis and thrombosis ${ }^{2 n d}$ ed. Willey-Backwell. North Carolina.2009;22:227-234

15. Astute KW. Kombinasi asetosal dan ekstrak buah mengkudu (morinda citrifolia l) dapat memperpanjang waktu perdarahan dan koagulasi pada mencit. [Tesis]. Denpasar: Universitas Udayana;2011.

16. Tullis JL, Surgenor DM, Baudanza P.Preserved Platelets: Their Preparation, storage and clinical use. In bloodjournal.hematologylibrary/org. 1959;14:456-475

17. KDIGO. Definition and classification of CKD: a position statement from Kidney Disease : improving global outcomer.2010

18. Wirawan R, Shodri. Uji ketelitian dan nilai rujukan agregasi trombosit dengan agonist ADP pada orang Indonesia dewasa di Jakarta menggunakan agregometer chronolog model 490. Jakarta.2006

19. Gandasoebrata R. Penuntun laboratorium klinik. Jakarta. Dian Rakyat.2007.h.7-10

20. Guven FMK, Yilmaz A, Aydin H, Korkmaz I, Ere SH.Platelet Aggregation responses in type 2 diabetes patients. 2010; 2: 708-12. 